\title{
Digestibility of animal and vegetable protein ingredients by pirarucu juveniles, Arapaima gigas
}

\section{Filipe dos Santos Cipriano1, Kauana Santos de Lima², Ricardo Henrique Bastos de Souza3, William Cristiane Teles Tonini ${ }^{4}$, Érica Bevitório Passinato ${ }^{5}$, Luís Gustavo Tavares Braga ${ }^{5}$}

\author{
${ }^{1}$ Universidade Federal de Minas Gerais, Belo Horizonte, MG, Brazil. \\ 2 Universidade Federal da Bahia, Salvador, BA, Brazil. \\ ${ }^{3}$ Universidade Federal de Rondônia, Presidente Médici, RO, Brazil. \\ ${ }^{4}$ Universidade do Estado da Bahia, Xique-Xique, BA, Brazil. \\ ${ }^{5}$ Universidade Estadual de Santa Cruz, Ilhéus, BA, Brazil.
}

\begin{abstract}
The objective of this study was to determine the apparent digestibility coefficients of energy, protein, and amino acids in protein ingredients by pirarucu juveniles. A test was conducted with six protein ingredients: meat and bone meal, fish meal, hydrolyzed feather meal, poultry by-product meal, soybean meal, and corn gluten meal. Three repetitions were used for each tested ingredient. A reference feed was used with $430 \mathrm{~g} \mathrm{~kg}^{-1}$ crude protein and $19.63 \mathrm{~kJ} \mathrm{~g}^{-1}$ gross energy. The test feeds consisted of the replacement of $30 \%$ of the reference feeds with the test ingredients. Chromium oxide was added to the feeds at $1 \mathrm{~g} \mathrm{~kg}^{-1}$ as an external marker. Eighteen juveniles with an average weight of $235 \pm 36 \mathrm{~g}$ were used. The best apparent digestibility coefficients of protein were found for fish meal, followed by the poultry by-product meal and meat and bone meal. However, except for gluten, all the tested ingredients presented protein digestibilities above 0.70 . The crude energy apparent digestibility coefficient was higher for animal ingredients, above 0.75 , than for vegetable ingredients, which presented values below 0.60 . Pirarucu efficiently uses the protein from the tested ingredients, regardless of origin. However, it has a preferential ability to use the energy from animal ingredients.
\end{abstract}

Key Words: amino acid, carnivore species, fish nutrition, nutritional value

\section{Introduction}

Pirarucu (Arapaima gigas) is a carnivorous fish and an important source of income for fishermen in the region around the Amazon basin. However, pirarucu fishing is limited and regulated by inspection and environmental agencies to keep the stock from being depleted and to ensure that ecological balance is maintained, as it is a species at the top of its food chain (Castello et al., 2011).

In recent years, this species has gained attention from the aquaculture industry because it presents both attractive characteristics for the development of its farming and a large size: it may reach more than $10 \mathrm{~kg}$ in a year. It has aerial respiration, a good carcass yield, and its meat is highly appreciated and valued (Imbiriba, 2001). Another important characteristic is that despite being a carnivorous fish, when it is well managed in captivity, it is not a cannibal species

Received October 28, 2015 and accepted June 14, 2016.

Corresponding author: Igtbraga@gmail.com

http://dx.doi.org/10.1590/S1806-92902016001000001

Copyright (c) 2016 Sociedade Brasileira de Zootecnia. This is an Open Access article distributed under the terms of the Creative Commons Attribution License (http://creativecommons.org/licenses/by/4.0/), which permits unrestricted use, distribution, and reproduction in any medium, provided the original work is properly cited. during its juvenile stage. After weaning, the fish accept inert food.

To formulate proper feeds for each species, it is fundamental to be aware of the digestibility of the ingredients. Digestibility information is necessary to prepare feeds that will lead to better yields, therefore optimizing feed costs, increasing productivity and profits, and reducing the environmental impact generated through excretion (Cho, 1987).

For carnivorous fish, the knowledge of animal and vegetable protein ingredient yields is crucial because large feed amounts are required to meet protein requirements. As protein-containing ingredients are the most costly ones, the possibility of using different sources may generate savings on the final cost of feeds. However, the volume of information available on captive pirarucu nutrition is limited (Cipriano et al., 2015), and it is inversely proportional to the rising number of fish farmers interested in its intensive production. Therefore, research efforts are required to collect data regarding the feed yield and nutritional needs of the species (Fracalossi and Cyrino, 2012).

This study aimed to determine the apparent digestibility of dry matter, crude protein, gross energy, and amino acids in animal and vegetable protein ingredients for pirarucu juveniles. 


\section{Material and Methods}

The experiment was conducted in Ilhéus, BA, Brazil, in accordance with ethical standards and approved by the Ethics and Biosafety Committee of Universidade Estadual de Santa Cruz (case no. 001/2015). We used 18 juvenile pirarucu with an average live weight of $235 \pm 36 \mathrm{~g}$; specimens were provided by the Canta Galo Farm, Ibirataia-BA. Three individuals were housed per tank in six tanks (310 L) that were later used as feeding tanks. The tanks were arranged in a closed circulation system using a water pump (Dancor ${ }^{\circledR}$, RJ, Brazil-75 HP) with biological filters, and constant aeration was provided by a blower (WEG of $1 \mathrm{HP}$ ).

Juveniles were subjected to period of adaptation to laboratory and routine management conditions for 10 days, during which they received the reference feed (Table 1) four times a day. During the adjustment period and the experimental period, daily cleaning was performed to remove feces and possible scraps of feed.

After that period, the selected fish remained in the tanks, which were used as feeding tanks. They received five meals a day: two in the morning $(8.00 \mathrm{~h}$ and $10.00 \mathrm{~h})$ and three in the afternoon ( $12.00 \mathrm{~h}, 14.00 \mathrm{~h}$, and $16.00 \mathrm{~h})$. For each meal tested, the fish went through a four-day adaptation period and then their feces were collected for a three-day period.

To collect the feces, the fish were transferred to the digestibility tanks $(200 \mathrm{~L}) 1 \mathrm{~h}$ after their last meal. The digestibility tanks had conical shapes, constant aeration, and

Table 1 - Composition of reference diet

\begin{tabular}{lc}
\hline Ingredient & Content $\left(\mathrm{g} \mathrm{kg}^{-1}\right)$ \\
\hline Soybean meal & 188.00 \\
Wheat bran & 140.00 \\
Corn gluten meal & 105.00 \\
Corn & 90.03 \\
Fish meal & 370.00 \\
Poultry by-product meal & 57.67 \\
Corn starch & 27.00 \\
Soybean oil & 8.45 \\
Mineral and vitamin mix & 7.00 \\
Sodium chloride & 3.50 \\
Cellulose & 2.15 \\
Chromic oxide III & 1.00 \\
BHT & 0.20 \\
Total & 1000 \\
Crude protein (g kg $\left.{ }^{-1}\right)$ & 432.40 \\
Gross energy (kJ g $\left.{ }^{-1}\right)$ & 19.63 \\
Ash (g kg ${ }^{-1}$ ) & 143.00 \\
\hline BHT - butylated hydroxytoluene. & \\
1 Mineral and vitamin mix per kg of product: vitamin A - 6,000,000 IU; vitamin D3 - \\
2,250,000 IU; vitamin E - 75,000 mg; vitamin K3 - 3,000 mg; vitamin thiamine \\
(B1) - 5,000 mg; riboflavin (B2) - 10,000 mg; pyridoxine - 8,000 mg; biotin - 2,000 mg; \\
ascorbic acid (vitamin C) - 192,500 mg; niacin - 30,000 mg; folic acid - 3,000 mg; \\
Fe - 100,000 mg; Cu - 600 mg; Mn - 60,000 mg; Zn - 150,000 mg; - 4,500 mg; \\
Cu - 15,000 mg; Co - 2,000 mg; Se - 400 mg. \\
\hline
\end{tabular}

biological filters and were equipped with collection devices in their bottoms, which were submersed in water and ice during the collection periods. At $7.00 \mathrm{~h}$ on the following day, the fish were transferred to the feeding tanks. The collection devices were detached so that the feces could be collected. The feces were packed in disposable aluminum containers to be dried in a forced-ventilation drying oven at $55^{\circ} \mathrm{C}$ for $24 \mathrm{~h}$.

The tanks were cleaned daily and the physical and chemical variables of the water were measured weekly. The $\mathrm{pH}$, temperature, and dissolved oxygen were 6.8 to 7.0, $26.8 \pm 0.43{ }^{\circ} \mathrm{C}$, and $7.2 \pm 1.43 \mathrm{mg} \mathrm{L}^{-1}$, respectively.

To prepare the experimental diets, a diet was formulated as a reference (Table 1) with the use of SUPER CRAC ${ }^{\mathbb{B}}$ software. The crude protein levels were the same as those found by Ituassú et al. (2005). The ingredients were ground in a knife mill, pushed through a $0.5 \mathrm{~mm}$ sieve, and homogenized. The mixture was previously moistened using water at $40{ }^{\circ} \mathrm{C}$. The feeds were processed in a meat grinder with a reversible function using a $2-\mathrm{mm}$ matrix. The feed granules were dried in a kiln $\left(55^{\circ} \mathrm{C}\right)$ with forced ventilation for $24 \mathrm{~h}$ and disintegrated to present the proper size for the fish to feed on them.

Test feeds were prepared using a mixture of $70 \%$ reference feed and $30 \%$ of the ingredient to be tested. The apparent digestibility coefficients of the following six protein ingredients were tested: meat and bone meal, fish meal, hydrolyzed feather meal, poultry by-product meal, soybean meal, and corn gluten meal (Table 2). For each ingredient tested, three repetitions were used and obtained every seven days. The feces were collected in the last four days of each cycle.

The apparent digestibility coefficients of the feed and the test ingredients were determined using indirect methods with the use of chromium oxide $\left(1 \mathrm{~g} \mathrm{~kg}^{-1}\right)$ as the external marker. The elemental contents were represented in the feeds and in the feces. The apparent digestibility coefficients of the feeds (ADCFE) were calculated according to De Silva (1989), using the following formula:

$$
\text { ADCFE }=100-\frac{\% \mathrm{Cr}_{2} \mathrm{O}_{3} \text { feed }}{\% \mathrm{Cr}_{2} \mathrm{O}_{3} \text { feces }} \times \frac{\% \text { nutrients or gross energy feces }}{\% \text { nutrients or gross energy feed }}
$$

The coefficients of digestibility of the ingredients $\left(\mathrm{ADC}_{\mathrm{I}}\right)$ were calculated using the methodology employed by Bureau et al. (1999), with the following formula:

$$
\mathrm{ADCI}=\frac{\mathrm{ADCTF}-\mathrm{ADCRF} \times 0.7}{\mathrm{ADCTF} \times 0.3},
$$

in which ADCI is the apparent digestibility coefficient of nutrients or energy in the ingredients; ADCTF is the apparent digestibility coefficient of nutrients or energy 
Table 2 - Nutritional composition based on the dry matter from ingredients assessed during the analysis of digestibility by pirarucu (Arapaima gigas)

\begin{tabular}{|c|c|c|c|c|c|c|}
\hline & \multicolumn{6}{|c|}{ Ingredient } \\
\hline & Corn gluten meal & Feather meal & Fish meal & Meat and bone meal & Poultry by-product meal & Soybean meal \\
\hline Dry matter $\left(\mathrm{g} \mathrm{kg}^{-1}\right)$ & 88.95 & 90.27 & 92.44 & 93.19 & 97.17 & 88.27 \\
\hline Crude protein $\left(\mathrm{g} \mathrm{kg}^{-1}\right)$ & 275.25 & 706.78 & 578.34 & 437.47 & 604.47 & 508.71 \\
\hline Lipids $\left(\mathrm{g} \mathrm{kg}^{-1}\right)$ & 95.82 & 170.26 & 229.90 & 168.01 & 200.17 & 107.59 \\
\hline $\operatorname{Ash}\left(\mathrm{g} \mathrm{kg}^{-1}\right)$ & 60.54 & 49.78 & 218.79 & 380.43 & 66.69 & 64.85 \\
\hline \multicolumn{7}{|l|}{ Amino acid $\left(\mathrm{g} \mathrm{kg}^{-1}\right)$} \\
\hline Arginine & 7.7 & 47.6 & 34.5 & 31.8 & 37.2 & 34.5 \\
\hline Aspartate & 12.8 & 50.3 & 42.3 & 28.7 & 48.6 & 52.4 \\
\hline Cysteine & 4.8 & 33.9 & 3.7 & 1.7 & 7.3 & 6.5 \\
\hline Glutamate & 42.2 & 77.0 & 62.7 & 48.1 & 73.1 & 82.8 \\
\hline Glycine & 9.8 & 53.5 & 66.0 & 74.3 & 42.2 & 20.9 \\
\hline Histidine & 5.9 & 9.8 & 9.1 & 5.8 & 10.7 & 12.2 \\
\hline Isoleucine & 7.9 & 32.4 & 16.5 & 10.1 & 23.4 & 21.9 \\
\hline Proline & 22.7 & 62.5 & 35.0 & 41.5 & 29.0 & 22.6 \\
\hline Serine & 10.0 & 70.8 & 21.2 & 15.2 & 25.7 & 21.5 \\
\hline Threonine & 8.3 & 33.6 & 20.0 & 11.9 & 24.0 & 17.4 \\
\hline Valine & 11.5 & 48.6 & 21.6 & 15.8 & 28.9 & 24.0 \\
\hline
\end{tabular}

in the test feed; and ADCRF is the apparent digestibility coefficient of nutrients or energy in the reference feed.

After drying and checking for the possible presence of scales, the samples were identified, stored in plastic containers, and kept in a freezer $\left(-10{ }^{\circ} \mathrm{C}\right)$ for further analyses of dry matter (DM), mineral matter (MM), crude protein $(\mathrm{CP})$, gross energy $(\mathrm{CE})$, and chromium concentrations.

The analyses of crude protein, gross energy, dry matter, and mineral matter were conducted as per the methodology of AOAC (2000). The analyses of amino acids from feces and feeds were conducted by ion-exchange chromatography by Evonik Industries AG using the methodology of White et al. (1986). The chromium concentrations were analyzed with the Inductively Coupled Plasma-Optical Emission Spectrometer (ICP OES), model Varian 710-ES, series using the methodology of Giné-Rosias (1998).

The data were subjected to one-way analysis of variance (ANOVA) and compared by the Scott-Knott test $(\mathrm{P}<0.05)$, using the statistical software R Core Team (2011).

\section{Results}

The apparent digestibility coefficients (ADC) of dry matter, crude protein, and gross energy of the evaluated ingredients for pirarucu juveniles presented significant differences $(\mathrm{P} \leq 0.05)$ (Table 3$)$.
The best apparent digestibility coefficients of dry matter (ADCDM) were found for the poultry by-product meal and fish meals, both of which were above $89.0 \%$. The ADCDM of feather meal, soybean meal, and meat and bone meal had intermediate values, ranging from $70.8 \%$ to $79.5 \%$. The corn gluten meal presented the lowest ADCDM.

The fish meal had the best apparent digestibility coefficients for crude protein (ADCCP), followed by the poultry by-product meal and meat and bone meal. They were followed by the soybean meal and hydrolyzed feather meal. The corn gluten meal had the lowest ADCCP.

The ingredients that presented the highest apparent digestibility coefficients of amino acids (ADCAA) were fish meal, meat and bone meal, and poultry byproduct meal, with an average of $90.9 \%$. For soybean meal, ADCAA classified in groups with higher values or intermediate values were found, with an average of $85.8 \%$. The lowest ADCAA values were found for the hydrolyzed feather meal and the corn gluten meal, with an average of $70.8 \%$.

For the apparent digestibility coefficients of gross energy (ADCCE), the ingredients with the best digestibilities were the poultry by-product meal and fish meal. The feather meal and meat and bone meal had intermediate ADCCE. The lowest ADCCE were found for the corn gluten meal and soybean meal. 
Table 3 - Apparent digestibility coefficients (ADC) for dry matter, crude protein, gross energy, and amino acid of the tested ingredients in pirarucu (Arapaima gigas)

\begin{tabular}{|c|c|c|c|c|c|c|c|c|}
\hline \multirow{2}{*}{$\operatorname{ADC}(\%)$} & \multicolumn{6}{|c|}{ Ingredient } & \multirow{2}{*}{ CV $(\%)$} & \multirow{2}{*}{ P-value } \\
\hline & Corn gluten meal & Feather meal & Fish meal & Meat and bone meal & Poultry by-product meal & Soybean meal & & \\
\hline Dry matter & $61.2 \mathrm{c}$ & $79.5 b$ & $89.2 \mathrm{a}$ & $70.8 \mathrm{~b}$ & $93.5 \mathrm{a}$ & $76.7 \mathrm{~b}$ & 7.56 & 0.001 \\
\hline Crude protein & $74.2 \mathrm{~d}$ & $80.4 \mathrm{c}$ & $97.6 \mathrm{a}$ & $89.4 b$ & $90.3 b$ & $83.8 \mathrm{c}$ & 2.81 & 0.001 \\
\hline Gross energy & $59.8 \mathrm{c}$ & $83.3 b$ & $89.1 \mathrm{a}$ & $75.4 \mathrm{~b}$ & $96.2 \mathrm{a}$ & $58.0 \mathrm{c}$ & 6.45 & 0.001 \\
\hline \multicolumn{9}{|l|}{ Amino acid } \\
\hline Alanine & $75.1 \mathrm{~b}$ & $73.2 b$ & $99.3 \mathrm{a}$ & $89.0 \mathrm{a}$ & $96.3 \mathrm{a}$ & $794 b$ & 7.56 & 0.001 \\
\hline Cysteine & $71.1 \mathrm{~b}$ & $59.3 b$ & $86.4 \mathrm{a}$ & $70.7 b$ & $69.1 \mathrm{~b}$ & $80.7 \mathrm{a}$ & 11.16 & 0.022 \\
\hline Glutamate & $82.2 \mathrm{~b}$ & $73.3 b$ & $95.3 \mathrm{a}$ & $87.2 \mathrm{a}$ & $94.6 \mathrm{a}$ & $93.7 \mathrm{a}$ & 5.93 & 0.001 \\
\hline Glycine & $67.1 \mathrm{c}$ & $81.3 b$ & $95.8 \mathrm{a}$ & $88.8 \mathrm{a}$ & $97.4 \mathrm{a}$ & $83.5 b$ & 7.89 & 0.001 \\
\hline Histidine & $75.7 b$ & $72.1 \mathrm{~b}$ & $93.2 \mathrm{a}$ & $87.8 \mathrm{a}$ & $95.4 \mathrm{a}$ & $93.9 \mathrm{a}$ & 7.28 & 0.002 \\
\hline Isoleucine & $62.7 \mathrm{~b}$ & $71.4 \mathrm{~b}$ & $95.0 \mathrm{a}$ & $85.7 \mathrm{a}$ & $92.3 \mathrm{a}$ & $81.6 \mathrm{a}$ & 10.11 & 0.003 \\
\hline Leucine & $78.2 b$ & $69.2 b$ & $96.1 \mathrm{a}$ & $89.2 \mathrm{a}$ & $90.8 \mathrm{a}$ & $81.2 b$ & 8.18 & 0.005 \\
\hline Threonine & $62.9 \mathrm{~b}$ & $69.0 \mathrm{~b}$ & $96.5 \mathrm{a}$ & $85.0 \mathrm{a}$ & $92.2 \mathrm{a}$ & $79.7 \mathrm{a}$ & 9.55 & 0.001 \\
\hline Valine & $65.7 b$ & $65.1 \mathrm{~b}$ & $95.4 \mathrm{a}$ & $86.7 \mathrm{a}$ & $88.9 \mathrm{a}$ & $83.0 \mathrm{a}$ & 9.99 & 0.002 \\
\hline
\end{tabular}

$\mathrm{CV}$ - coefficient of variation.

\section{Discussion}

Carnivorous fish have high lipase and protease levels (Furné et al., 2005), which benefit the digestibility of animal protein ingredients, while production of enzymes is influenced by factors such as environmental changes (Moura et al., 2007) and dietary particle size (Polese et al., 2010). That explains why the best ADCDM were found for the poultry by-product meal and fish meal. Similar ADCDM values were found by Braga et al. (2008) for fish meal and meat and bone meals - $95.2 \%$ and $95.7 \%$ - respectively, for dourado juveniles (33.5 g). However, Zhou et al. (2004) found similar ADCDM rates for fish meal (87.6\%) and lower rates for poultry by-product meal $(80.9 \%)$ for cobia juveniles (Rachycentron canadum) (10 g).

Among the animal ingredients, meat and bone meal had the worst dry matter digestibility, even though the protein digestibility was high. The composition of that ingredient was variable, and meals with large bone amounts tended to present lower ADCDM (Silva et al., 2013). The meat and bone meal had 38\% mineral matter, which demonstrated a high amount of bone in its composition.

In studies with carnivorous fish, high protein digestibility values were observed for fish meal, as found for oscar (Astronotus ocellatus), 92.8\% (Nascimento et al., 2012); dourado (Salminus brasiliensis), 94.3\% (Borghesi et al., 2009); spotted sorubim (Pseudoplatystoma corruscans), 84.1\% (Gonçalves and Carneiro, 2003); striped surubim (Pseudoplatystoma reticulatum), 82.8\%
(Silva et al., 2013); cobia (Rachycentron canadum), 96.3\% (Zhou et al., 2004); and sea bass (Dicentrachus labrax), 93.5\% (Davies et al., 2009).

Fish meals differ with regard to their quality. They may present excess minerals in their composition, generally due to the high presence of scales and bones, which results in reduced protein contents and nutritional values (Sampaio et al., 2001).

Silva et al. (2013), in a study with $P$. reticulatum, observed a similar ADCCP for meat and bone meal (87.4\%), a higher ADCCP for poultry by-product meal (99.4\%), and a lower ADCCP for soybean meal. Lee (2002) observed similar ADCCP values for meat and bone meal (90.0\%) and soybean meal (84.0\%) for Sebastes schlegeli. Similar values were observed by Borghesi et al. (2009) for poultry by-product meal for dourado (Salminus brasiliensis) (91.3\%).

The ADCCP of feather meal and corn gluten meal in pirarucu were lower than those found for dourado $(91.3 \%$ and $93.5 \%$, respectively) (Borghesi et al., 2009) and for corn gluten meal (94.4\%) for cobia (Zhou et al., 2004). However, the ADCCP were higher than those found by Gonçalves and Carneiro (2003) for feather meal (39.5\%) for spotted sorubim (P. corruscans).

The protein quality of an ingredient depends on the profile of the amino acids and their availability (Rollin et al., 2003). Although the ADCCP is directly related to the digestibility of amino acids, there may be differences in ADCCP for some of them (Zhang et al., 2015). The 
formulation of diets based on the amount of available amino acids may result in considerably improved performances (Rawles et al., 2006).

Lysine is considered the first limiting amino acid to fish growth (Abboudi et al., 2006). The lysine requirements of commonly farmed fish species fall between 32 and $62 \mathrm{~g} \mathrm{~kg}^{-1}$ of the total consumed protein (Wilson, 2002). Zhou et al. (2004) found a lysine ADC for cobias close to those found in this study for fish meal $(97.5 \%)$, meat and bone meal $(84.5 \%)$, and poultry by-product meal $(91.8 \%)$. However, they found a higher value for corn gluten meal $(96.9 \%)$. Similarly, methionine is an indispensable amino acid for normal growth for fish (Zhou et al., 2006). The methionine ADC obtained were close to those found for cobias by Zhou et al. (2004) for fish meal (95.9\%) and poultry by-product meal $(92.5 \%)$.

Vegetable ingredients presented an ADCCE below $60.0 \%$, whereas the animal ones presented values above $75.0 \%$. These results demonstrated that pirarucu had a lower capacity to digest energy in vegetable ingredients. Higher ADCCE for animal ingredients were also observed for the carnivorous fish $R$. canadum (Zhou et al., 2004), Sebastes schlegeli (Lee, 2002), and P. corruscans (Gonçalves and Carneiro, 2003).

Studies with trout (Oncorhynchus mykiss) and European eel (Anguilla anguilla), also carnivorous species, demonstrated that the production of alpha-amylase was reduced and hindered energy digestion as carbohydrates. In turn, lipase activity may be higher than that found for omnivorous species (Hidalgo et al., 1999; Furné et al., 2005).

Nonetheless, fish are able to modify their enzyme production throughout time, according to the food they receive. This adaptation varies according to the species. Lundstedt et al. (2004) assessed the response of the enzyme profile of $P$. corruscans given different feeds and found increased amylase production with high levels of carbohydrates.

Braga et al. (2008) assessed the digestibility of ingredients in dourado juveniles (35.51 g) and observed close ADCCE rates for poultry by-product meal $(95.3 \%)$ and fish meal (93.9\%) and better digestibilities for meat and bone meal (75.4\%) and corn gluten meal (95.7\%). The ADCCE for soybean meal was similar to the $61.7 \%$ found by Gonçalves and Carneiro (2003) for P. corruscans (9.8 g).

The feather meal ADCCE for pirarucu was similar to those found by Bureau et al. (1999) for trout juveniles $(81.0 \%, 24 \mathrm{~g})$ and by Lee (2002) for Sebastes schlegeli juveniles $(85.0 \%, 30 \mathrm{~g})$. However, Silva et al. (2013) found worse digestibility for surubim $(53.8 \%)$. In addition to the differences among the studied fish species, the lack of standardization for certain ingredients, such as the amount of ash, contributed to different values.

\section{Conclusions}

Pirarucu adapts to the use of feeds with animal and vegetable ingredients. The protein in the tested ingredients is well digested regardless of its origin. However, the energy digestibility from vegetable ingredients is smaller than that from animal ingredients.

\section{Acknowledgments}

This project was supported by Coordination for the Improvement of Higher Education Personnel (CAPES) and Bahia Research Foundation (FAPESB - TSC0015/2012), Brazil. The Canta Galo Farm (Bahia, Brazil) provided the fish for this project.

\section{References}

Abboudi, T.; Mambrini, M.; Ooghe, W.; Larondelle, Y. and Rollin, X. 2006. Protein and lysine requirements for maintenance and for tissue accretion in Atlantic salmon (Salmo salar) fry. Aquaculture 261:369-383.

AOAC - Association of Official Analytical Chemists. 2000. Official methods of analysis. 17th ed. Horwitz, W., ed. Gaithersburg, MD, USA.

Borghesi, R.; Dairiki, J. K. and Cyrino, J. E. P. 2009. Apparent digestibility coefficients of selected feed ingredients for dourado Salminus brasiliensis. Aquaculture Nutrition 15:453-458.

Braga, L. G. T.; Borghesi, R. and Cyrino, J. E. P. 2008. Apparent digestibility of ingredients in diets for Salminus brasiliensis. Pesquisa Agropecuária Brasileira 43:271-274.

Bureau, D. P.; Harris, A. M. and Cho, C. Y. 1999. Apparent digestibility of rendered animal protein ingredients for rainbow trout (Oncorhynchus mykiss). Aquaculture 180:345-358.

Castello, L.; Stewart, D. J. and Arantes, C. C. 2011. Modeling population dynamics and conservation of arapaima in the Amazon. Reviews in Fish Biology and Fisheries 21:623-640.

Cho, C. Y. 1987. La energia en La nutrición de los peces. p.197-237. In: Nutrición en acuicultura II. Espinosa de los Monteros, J. and Labarta, U., eds. Madrid, España,

Cipriano, F. S.; Lima, K. S.; Passinato, E. B.; Jesus, R. M.; Magalhães Júnior, F. O. M.; Tonini, W. C. T. and Braga, L. G. T. 2015. Apparent digestibility of energetic ingredients by pirarucu juveniles, Arapaima gigas (Schinz, 1822). Latin American Journal Aquatic Research 43:786-791.

Davies, S. J.; Gouveia, A.; Laporte, J.; Woodgate, S. L. and Nates, S. 2009. Nutrient digestibility profile of premium (category III grade) animal protein by-products for temperate marine fish species (European sea bass, gilthead sea bream and turbot). Aquaculture Research 40:1759-1769.

De Silva, S. S. 1989. Digestibility evaluations of natural and artificial diets. Asian Fisheries Society Special Publication 4:36-45.

Fracalossi, D. M. and Cyrino, J. E. P. 2012. Nutriaqua: nutrição e alimentação de espécies de interesse para a aquicultura brasileira. 
Sociedade Brasileira de Aquicultura e Biologia Aquática, Florianópolis.

Furné, M.; Hidalgo, M. C.; López, A.; García-Gallego, M.; Morales, A. E.; Domezain, A., Domazainé, J. and Sanz, A. 2005. Digestive enzyme activities in Adriatic sturgeon Acipenser naccarii and rainbow trout Oncorhynchus mykiss. A comparative study. Aquaculture 250:391-398.

Giné-Rosias, M. F. G. 1998. Espectrometria de emissão atômica com plasma acoplado indutivamente: (ICP-AES). CENA/USP, Piracicaba.

Gonçalves, E. G. and Carneiro, D. J. 2003. Apparent digestibility coefficients of protein and energy of some ingredients used in diets for pintado, Pseudoplatystoma corruscans (Agassiz, 1829). Revista Brasileira de Zootecnia 32:779-786.

Hidalgo, M. C.; Urea, E. and Sanz, A. 1999. Comparative study of digestive enzymes in fish with different nutritional habits. Proteolytic and amylase activities. Aquaculture 170:267-283.

Imbiriba, E. P. 2001. Production potential of pirarucu, Arapaima gigas, in captivity. Acta Amazonica 31:299-316.

Ituassú, D. R.; Pereira-Filho, M.; Roubach, R.; Crescêncio, R.; Cavero B. A. S. and Gandra, A. L. 2005. Crude protein levels for juvenile pirarucu. Pesquisa Agropecuária Brasileira 40:255-259.

Lee, S. M. 2002. Apparent digestibility coefficients of various feed ingredients for juvenile and grower rockfish (Sebastes schlegeli). Aquaculture 207:79-95.

Lundstedt, L. M.; Melo, J. F. B. and Moraes, G. 2004. Digestive enzymes and metabolic profile of Pseudoplatystoma corruscans (Teleostei: Siluriformes) in response to diet composition. Comparative Biochemistry and Physiology Part B: Biochemistry and Molecular Biology 137:331-339.

Moura, G. S.; Oliveira, M. G. A.; Lanna, E. T. A.; Maciel Junior, A. and Maciel, C. M. R. R. 2007. Performance and amylase activity in Nile tilapia submitted to different temperatures. Pesquisa Agropecuária Brasileira 42:1609-1615.

Nascimento, T. M. T.; Fabregat, T. H. P.; Rodrigues, L. A.; Sakomura, N. K. and Fernandes, J. B. K. 2012. Effects of different sampling intervals on apparent protein and energy digestibility of common feed ingredients by juvenile oscar fish (Astronotus ocellatus). Acta Scientiarum. Animal Sciences 34:143-147.
Polese, M. F.; Vidal Junior, M. V.; Mendonça, P. P.; Tonini, W. C. T.; Radael, M. C. and Andrade, D. R. 2010. Effect of corn granulometry on performance of juvenile pacu, Piaractus mesopotamicus Holmberg, 1887. Arquivo Brasileiro de Medicina Veterinária e Zootecnia 62:1469-1477.

Rawles, S. D.; Riche, M.; Gaylord, T. G.; Webb, J.; Freeman, D. W. and Davis, M. 2006. Evaluation of poultry by-product meal in commercial diets for hybrid striped bass (Morone chrysops $q \times$ M. saxatilis $\widehat{\jmath}$ ) in recirculated tank production. Aquaculture 259:377-389.

Rollin, X.; Mambrini, M.; Abboudi, T.; Larondelle, Y. and Kaushik, S. J. 2003. The optimum dietary indispensable amino acid pattern for growing Atlantic salmon (Salmo salar L.) fry. British Journal Nutrition 90:865-876

Sampaio, F. G.; Hisano, H.; Yamaki, R. A.; Kleemann, G. K.; Pezzato, L. E. and Barros M. M. 2001. Digestibilidade aparente das farinhas de peixe nacional e importada e das farinhas de sangue tostada e spray-dried, pela tilápia-do-nilo, Oreochromis niloticus (L.). Acta Scientiarum. Animal Sciences 23:891-896.

Silva, T. S. C.; Moro, G. V.; Silva, T. B. A.; Dairiki, J. K. and Cyrino, J. E. P. 2013. Digestibility of feed ingredients for the striped surubim Pseudoplatystoma reticulatum. Aquaculture Nutrition 19:491-498.

Wilson, R. P. 2002. Amino acids and proteins. p.144-175. In: Fish nutrition. 3rd ed. Halver, J. E. and Hardy, R. W., eds. Academic Press, San Diego, CA.

White, J. A.; Hart, R. J. and Fry, J. C. 1986. An evaluation of the waters pico-tag system for the amino-acid-analysis of food materials. Journal of Automatic Chemistry 8:170-177.

Zhang, C. X.; Huang, K. K.; Wang, L.; Song, K.; Zhang, L. and Li, P. 2015. Apparent digestibility coefficients and amino acid availability of common protein ingredients in the diets of bullfrog, Rana (Lithobates) catesbeiana. Aquaculture 437:38-45.

Zhou, Q. C.; Tan, B. P.; Mai, K. S. and Liu, Y. J. 2004. Apparent digestibility of selected feed ingredients for juvenile cobia Rachycentron canadum. Aquaculture 241:441-451.

Zhou, Q. C.; Wu, Z. H.; Tan, B. P.; Chi, S. Y. and Yang, Q. H. 2006. Optimal dietary methionine requirement for juvenile cobia (Rachycentron canadum). Aquaculture 258:551-557. 